\title{
Output of selenium in milk, urine, and feces is proportional to selenium intake in dairy cows fed a total mixed ration supplemented with selenium yeast
}

\author{
G. P. Walker, ${ }^{*}$ F. R. Dunshea,$\dagger^{1}$ J. W. Heard, ${ }^{*}$ C. R. Stockdale, ${ }^{* 2}$ and P. T. Doyle ${ }^{*}$ \\ ${ }^{*}$ Future Farming Systems Research, Department of Primary Industries, Kyabram Centre, 120 Cooma Road, Kyabram, Victoria 3620, Australia \\ †National Centre of Excellence in Functional Foods, Future Farming Systems Research, Department of Primary Industries, Werribee Centre, \\ 600 Sneydes Road, Werribee, Victoria 3030, Australia
}

\begin{abstract}
Fifteen rumen fistulated Holstein cows in late lactation and fed a total mixed ration offered ad libitum were supplemented with Se yeast to provide 0, 11, 20, 30 , or $42 \mathrm{mg}$ of supplemental Se/day to test the hypothesis that amounts of Se secreted in milk, excreted in urine and feces, and apparently retained in tissues would increase in direct proportion to Se intake. Onehalf of the yeast supplement was placed directly into the rumen through the fistula of each cow just before milking in the morning and again in the evening, and estimates of average daily excretion of Se were made using total collections of urine and feces from 25 to $31 \mathrm{~d}$ after treatments commenced. Amounts of Se secreted daily in milk and apparently retained in tissues increased linearly with average daily intake of Se. The amount of Se excreted in feces and total excretion of Se in urine plus feces increased curvilinearly with Se intake, such that proportionately less Se was excreted as the amount of Se fed increased. On average, total Se excretion accounted for $66 \%$, Se secretion in milk accounted for $17 \%$, and Se apparently retained in tissues accounted for $17 \%$ of total Se intake by cows. Thus, in herds fed large amounts of Se yeast, most of the Se will be excreted and retained on-farm. High concentrations of Se will be found where urine and feces accumulate (e.g., yards and effluent ponds), and effluent management practices must be tailored to avoid environmental issues.
\end{abstract}

Key words: selenium yeast, secretion and excretion, dairy cow, environment

\section{INTRODUCTION}

Organically bound Se fed to ruminants has higher bioavailability (greater absorption across the gut) and bioactivity (greater production of seleno-proteins) com-

Received February 18, 2010.

Accepted June 9, 2010.

${ }^{1}$ Current address: Faculty of Land and Food Resources, The University of Melbourne, Parkville, Victoria 3010, Australia.

${ }^{2}$ Corresponding author: richard.stockdale@dpi.vic.gov.au pared with equivalent amounts of Se derived from an inorganic source such as sodium selenite (Knowles et al., 1999; Ortman and Pehrson, 1999; Boldizarova et al., 2005). Once absorbed, supplemental Se (organic or inorganic) is rapidly excreted in urine in animals fed to meet energy requirements for maintenance (Burk et al., 1973; Hidiroglou and Hoffman, 1975; Boldizarova et al., 2003). In metabolically active animals, however, the organically derived Se is more likely to be retained through nonspecific incorporation into proteins (Burk et al., 2001) and, in the case of lactating dairy cows, secreted in milk protein (Ortman and Pehrson, 1997; Knowles et al., 1999; Heard et al., 2004).

The amounts of organic Se used to produce Seenriched milk and dairy products may be 20 to 40 times higher than needed to prevent Se deficiency in livestock. Currently, these levels of Se intake are not permitted in some regions because of legislative restrictions (e.g., in the United States, FDA regulations limit Se supplementation of dairy cows to $0.3 \mathrm{mg} / \mathrm{kg}$ of DM). As human populations age, however, with an increasing number of people afflicted by cancers and other immune system issues, these restrictions may change because Se-enhanced milk protein has been shown to be highly bioavailable (McIntosh et al., 2008; Uglietta et al., 2008) and potentially very effective at reducing diseases such as colon cancer (Hu et al., 2008). At these high levels of supplementation, however, there is little information describing relative rates of secretion and excretion of Se by cows. The apparent accumulation of Se in tissues of food animals or its accumulation in the environment have the potential to act as point sources of Se within the food chain (Zayed et al., 1998; Hintze et al., 2002; Lemly, 2004) and affect the efficiency of production of Se-enriched milk and dairy products (Knowles et al., 1999). The research described here tested the hypothesis that concentrations of Se in milk and blood and amounts of Se apparently accumulating in tissues, secreted in milk, or excreted in urine and feces by lactating dairy cows fed Se yeast would increase in direct proportion to daily Se intake up to about 40 $\mathrm{mg}$ of $\mathrm{Se} / \mathrm{cow}$. 


\section{MATERIALS AND METHODS}

\section{Experimental Design}

All procedures were conducted under protocols approved by the Melbourne Animal Ethics Committee of the Victorian Department of Primary Industries. The experiment was conducted at the Department of Primary Industries, Kyabram Centre, Victoria, Australia $\left(36^{\circ} 20^{\prime} \mathrm{S}, 145^{\circ} 04^{\prime} \mathrm{E}\right)$ between April 3 and May 11, 2006. Sixteen rumen fistulated Holstein cows in late lactation were fed a TMR offered ad libitum. They also received a daily supplement of $20 \mathrm{~g}$ of a low-Se yeast alone $(<0.01$ $\mathrm{mg} / \mathrm{kg}$ ), $20 \mathrm{~g}$ of a mixture of low-Se yeast and Sel-Plex [a high-Se yeast $(2,000 \mathrm{mg} / \mathrm{kg})$; Alltech Biotechnology, Nicholasville, KY] to provide 11,20 , or $30 \mathrm{mg}$ of $\mathrm{Se} /$ cow, or $20 \mathrm{~g}$ of high-Se yeast to provide $42 \mathrm{mg}$ of Se; the diet provided around $1 \mathrm{mg}$ of Se/cow. The concentrations of Se in whole blood and plasma were determined after $19 \mathrm{~d}$ on treatments. Average daily apparent retention of Se in tissues was estimated as the difference between daily Se intake and the sum of total secretion of Se in milk and excretion of Se in urine and feces over 7 consecutive days of total collection of milk, urine, and feces from 25 to $31 \mathrm{~d}$ after treatments commenced.

\section{Animals and Diets}

All cows were multiparous and had calved in the previous spring. Twelve cows were $150 \pm 21$ (average \pm SD) d pregnant at the start of the total collection. The remaining 4 cows had no detectable products of conception before the start of the experiment. Other descriptors of the physiological state and production characteristics of the experimental cows were as follows: BW, $598 \pm 39.5 \mathrm{~kg}$; age, $53 \pm 6.1 \mathrm{mo}$; stage of lactation, $246 \pm 18.1 \mathrm{~d}$ postpartum; BCS, $3.9 \pm 0.30$ units on the 8-point scale of Earle (1976); milk yield, $17.1 \pm 2.81 \mathrm{~kg} / \mathrm{d}$; milk protein, $3.48 \pm 0.237 \%$; milk fat, $3.92 \pm 0.788 \%$; lactose, $4.90 \pm 0.218 \%$; and SCC, $93 \pm$ $65.8 \times 10^{3}$ cells $/ \mathrm{mL}$.

Cows were milked daily at 0600 and $1600 \mathrm{~h}$. They were individually fed a TMR with an average composition of $33.5 \%$ corn silage, $30.6 \%$ alfalfa hay (good quality, sun-cured, green), $24.3 \%$ cracked barley grain, $10.7 \%$ canola meal, and $0.9 \%$ mineral mix (on a DM basis). The mineral mix consisted of $75 \%$ dicalcium phosphate and $25 \%$ sodium chloride by weight. The total feed on offer each day was divided into 2 equal portions and fed following each milking, at 0630 and $1630 \mathrm{~h}$. The TMR provided about $11.0 \mathrm{MJ}$ of $\mathrm{ME} / \mathrm{kg}$ of $\mathrm{DM}$, and had 16.0 and $34.4 \% \mathrm{CP}$ and $\mathrm{NDF} / \mathrm{kg}$ of DM, respectively, and met or exceeded guidelines (as defined by CSIRO, 2007) for intakes of macrominerals (\% of
DM: Ca, 0.58; K, 1.29; Mg, 0.25; Na, 0.18; P, 0.43; S, $0.23)$ and microminerals (mg/kg DM: $\mathrm{Cu}, 6.5 ; \mathrm{Fe}, 200$; Mn, 46; Zn, 28; Se, 0.063).

The range of concentrations of supplemental Se $(0$, 11, 20,30, and $42 \mathrm{mg}$ of $\mathrm{Se} / 20$-g dose) was produced by using combinations of low-Se killed torula yeast and Se-enriched torula yeast with a powdered soluble foodgrade dye (CAS No. 915-67-3, amaranth; All Colour Supplies, Parania, NSW, Australia) in a rotary barrel mixer, with the food dye $(0.25 \% \mathrm{wt} / \mathrm{wt})$ used as an indicator of homogeneity of the mixture. Half the daily dose was placed directly into the rumen through the cannula around the start of both the a.m. and p.m. feeds.

The amount of TMR offered to each cow was adjusted twice weekly so that each day's refusals remained around 5 to $10 \%$ of feed on offer based on the DMI average of the previous $3 \mathrm{~d}$. After $7 \mathrm{~d}$ on the TMR, cows were allocated to 1 of the 5 treatments using stratified randomization based on milk protein yield, DMI, BCS, and pregnancy status, with 3 cows allocated to each of the 0,11, 20, and $42 \mathrm{mg}$ supplemental Se treatments and 4 cows allocated to the $30 \mathrm{mg}$ supplemental Se treatment. Cows entered metabolism stalls after $21 \mathrm{~d}$ on treatments, and total collections of urine and feces were undertaken over 7 consecutive days, from 25 to 31 $\mathrm{d}$ after treatments commenced. One cow from the 20 mg treatment group was removed from the experiment $2 \mathrm{~d}$ after entering the metabolism unit because of injury, reducing the total number of experimental animals to 15. No changes were made to the feeding and treatment regimens during the total collection except that feed refusals were not removed until just before the next milking.

\section{Sampling and Analyses}

A representative sample of feed on offer was taken daily and stored at $-20^{\circ} \mathrm{C}$. Refusals exceeding about $50 \mathrm{~g}$ of wet weight were collected daily for each cow and stored at $-20^{\circ} \mathrm{C}$. Each Monday, the previous stored samples (from the past $7 \mathrm{~d}$ ) of feed on offer (to all cows) were bulked, and refusals were bulked for individual cows. Two subsamples were taken from each of these composite samples, the first being used to determine $\mathrm{DM}$ at $100^{\circ} \mathrm{C}$ to constant weight and the second freezedried to constant vacuum for determination of in vitro DM digestibility using a pepsin-cellulase technique (Clarke et al., 1982), total $\mathrm{N}$ concentration by Leco $\mathrm{N}$ analyzer (Leco Corp., St Joseph, MI), and NDF (Van Soest et al., 1991). Crude protein concentration of feeds and refusals was calculated as total $\mathrm{N} \times 6.25$. Total collection of urine and feces was undertaken using equipment described by Hughes (1963) and procedures 
described by Auldist et al. (1999). Urine was stabilized during collection by the addition of $100 \mathrm{~mL}$ of glacial acetic acid to the collection bin at the start of each day's collection and the addition of another $100 \mathrm{~mL}$ about $10 \mathrm{~h}$ later. The 24 -h collections of urine and feces from each cow were weighed each day. One subsample of feces was taken for determination of DM content, as for feed on offer, and a second subsample was dried at $60^{\circ} \mathrm{C}$ to constant weight, with this subsample being used for the production of a single composite sample representative of the total fecal DM output from each cow over the $7 \mathrm{~d}$ of total collection. The $\mathrm{pH}$ of a $0.5 \%$ (wt/wt) subsample of urine was adjusted to a value of 4 by the drop-wise addition of $2 \mathrm{M} \mathrm{NaOH}$ or $\mathrm{HCl}$, as required, and then stored at $-20^{\circ} \mathrm{C}$, with this subsample being used for the production of a single composite sample representative of the total urine output from each cow over the $7 \mathrm{~d}$ of total collection.

Individual milk yields were measured at each milking before the experiment began and throughout the experimental period. A representative sample of milk (22 $\mathrm{g}$ of sample/ $\mathrm{kg}$ of milk) was obtained at each milking from all cows during the excreta collection period using standard herd recording equipment (HI sample meter, Tru-Test Pty. Ltd., Auckland, New Zealand). Sufficient preservative (Bronopol, Merck Pty. Ltd., Kilsyth, Australia) was added to each milk sample at the time of collection to give a final concentration of 0.03 to $0.04 \%$ (wt/wt) before the samples were stored at $-20^{\circ} \mathrm{C}$. These samples were analyzed for fat, protein, and lactose concentrations, and SCC, by using a Foss 4000/5000 Combi (Foss Electric, Hillerød, Denmark). Milk samples from each cow were also analyzed for total milk Se concentration. Cows were weighed and their BCS assessed (Earle, 1976) before the experiment commenced. Two aliquots of blood were taken from the coccygeal vein of each cow into 10-mL BD Vacutainers (BD Vacutainer Systems, Plymouth, UK) containing lithium heparin. One sample was stored as whole blood and the other was centrifuged at 1,500 $\times g$ for $15 \mathrm{~min}$ and the plasma decanted and stored at $-80^{\circ} \mathrm{C}$ before analysis for total concentration of Se.

The concentration of total Se in all samples (TMR offered, feed refusals, milk, urine, feces, and blood) was determined using inductively coupled plasma mass spectrometry/vapor generation following digestion of samples in a mixture of nitric and perchloric acids as described by Heard et al. (2007). The limits of both detection and reporting were $1 \mu \mathrm{g}$ of $\mathrm{Se} / \mathrm{kg}$ of sample. This same digestate was used to determine the concentrations of macro- and microminerals in the TMR offered using inductively coupled plasma emission spectroscopy. The amounts of Se secreted in milk or excreted in urine or feces by individual cows were determined from the con- centration of Se multiplied by the total output of milk, urine, or fecal DM, respectively. We defined apparently retained Se as the difference between total Se intake and the sum of total Se output in milk, urine, and feces, and assumed that other losses of Se, such as that expired and eructated as volatile Se compounds or shed as hair and scurf, would be relatively small (Khirwar and Arora, 1975; Foster et al., 1986).

\section{Statistical Analyses}

Summary statistics (mean and SE) were used to characterize intakes of Se, DM, and $\mathrm{CP}$, and aspects of animal production for each treatment group. Linear regression (Genstat 8.1, Lawes Agricultural Trust, Rothamsted, UK) was used to describe the relationships between intake of Se and the concentrations of Se in milk, whole blood, and plasma, and to describe the relationships between intake of Se and the amounts of Se apparently retained in tissues, secreted in milk, and excreted in urine and feces. Linear regression was also used to model the relationship between the amount of Se secreted in milk and Se intake, protein yield, and stage of lactation using the combined data of this study and data reported by Heard et al. (2007).

\section{RESULTS}

Average intakes of DM and $\mathrm{CP}$ and the production and composition of milk did not differ between treatments (Table 1). The concentration of Se in milk ( $\mu \mathrm{g} /$ $\mathrm{kg})$ increased linearly with daily Se intake $(\mathrm{mg} / \mathrm{cow})$ :

$$
\begin{gathered}
\text { Milk Se }=6.1( \pm 11.60)+7.1( \pm 0.43) \\
\quad \times \text { total Se intake; } \\
\mathrm{R}^{2}=0.96(P<0.001) ; \text { residual standard deviation } \\
(\mathbf{R S D})=24.6 ; \mathrm{CV}=14.8 \% ; \mathrm{n}=15 .
\end{gathered}
$$

The amount of Se secreted daily in milk increased linearly with total Se intake (Figure 1a) and averaged $17 \pm$ $1.3 \%$ of the total amount of Se consumed. The amount of Se excreted in urine also increased linearly with total Se intake (Figure 1b), and average daily excretion of Se in urine was $26 \pm 2.2 \%$ of the total Se consumed. The amount of Se excreted in feces increased curvilinearly with Se intake, such that proportionately less Se was excreted as the amount of Se fed increased (Figure 1b). Average daily excretion of Se in feces was equivalent to $41 \pm 2.2 \%$ of the total amount of Se consumed daily. The daily excretion of Se (mg/cow) in urine plus feces increased curvilinearly with daily Se intake (mg/cow): 
Table 1. Average total intakes of Se, DM, and CP and milk production and composition by cows in each treatment group during the total collection of urine and feces (from 23 to $31 \mathrm{~d}$ on treatment)

\begin{tabular}{lcccccc}
\hline & \multicolumn{5}{c}{ Se yeast (mg of Se/cow per d) } & \\
\cline { 2 - 5 } Item & 0 & 11 & 20 & 30 & 42 & SE \\
\hline Intake & 18.9 & 19.7 & 17.4 & 17.6 & 19.6 & 1.64 \\
DM (kg/d) & 2.6 & 2.7 & 2.4 & 2.4 & 2.7 & 0.22 \\
CP (kg/d) & 1.2 & 12.2 & 21.1 & 31.1 & 43.2 & 0.10 \\
Selenium (mg/d) & 0.06 & 0.62 & 1.21 & 1.77 & 2.20 & - \\
Selenium (mg/kg of DM) & & & & & & \\
Milk production and composition & 18.3 & 22.7 & 16.0 & 20.7 & 21.4 & 3.08 \\
Milk yield (kg/d) & 3.72 & 3.44 & 3.78 & 3.60 & 3.52 & 0.172 \\
Milk protein (\%) & 4.82 & 4.01 & 4.64 & 4.43 & 3.52 & 0.655 \\
Milk fat (\%) & 4.98 & 5.03 & 4.89 & 4.97 & 5.00 & 0.095 \\
Milk lactose (\%) & 170 & 86 & 235 & 84 & 67 & 67.3 \\
SCC (× 1,000/mL) & 3 & 3 & 2 & 4 & 3 & - \\
Cows (n) & & & & & & \\
\hline
\end{tabular}

$$
\begin{gathered}
\text { Excreted Se }=-1.0( \pm 0.92)+0.91( \pm 0.098) \times \text { total } \\
\text { Se intake }-0.006( \pm 0.0021) \times \text { total Se intake } \\
\mathrm{R}^{2}=0.98(P<0.001) ; \mathrm{RSD}=1.5 \\
\mathrm{CV}=10.2 \% ; \mathrm{n}=15 .
\end{gathered}
$$

Total daily excretion of Se averaged $66 \pm 2.3 \%$ of the total amount of Se consumed daily. The apparent retention of Se in tissues increased linearly with Se intake (Figure 1c) and was equivalent to $17 \pm 2.3 \%$ of the total amount of Se consumed daily, on average.

The concentration of Se in whole blood increased linearly as Se intake increased (Figure 2). The concentration of Se in blood plasma increased curvilinearly with Se intake with proportionately less Se in blood plasma as total Se intake increased (Figure 2). The ratios of plasma Se to blood Se were 0.35, 0.60, 0.59, 0.61, and 0.65 for cows fed diets supplemented with $0,11,20,30$, and $42 \mathrm{mg}$ of Se from Se yeast.

\section{DISCUSSION}

The concentration of Se in the milk of individual cows was almost wholly determined by Se intake under the feeding and management conditions applied in this study. The relationship between the concentration of Se in milk and total intake of Se observed in this study is consistent with the findings of Heard et al. (2007), which were developed over a smaller range of daily intake of total Se (1 to $19 \mathrm{mg}$ of Se/cow) and included cows in both early and late lactation grazing pasture and supplemented with cereal grain-based concentrates (Figure 3). Despite dietary differences between studies, more than $98 \%$ of the variation in the concentration of Se in milk is explained by total Se intake when determined using treatment averages from the combined data sets. The strength of this relationship suggests that the type of feeding system and the stage of lactation of cows used to produce Se-enriched milk may not be important factors in determining the concentration of Se in milk in response to feeding Se yeast.

The amount of Se secreted daily in milk as a proportion of Se intake reflects the efficiency of recovery of Se from feeding Se yeast. The proportion of Se consumed that appeared in milk in this study was small (17\%) but similar to values reported by Heard et al. (2007) by cows in late lactation (10-14\%). Heard et al. (2007) also reported that cows in early lactation secreted a much greater proportion of Se intake in milk compared with their late-lactation cohorts (20-28 versus $10-14 \%$ for early versus late lactation). This 2-fold difference indicates that average intake of Se alone is inadequate as a predictor of the amount of Se secreted in milk.

Prediction of the amounts of Se secreted in milk by cows fed Se yeast are likely to be most useful when the predictions are based on milk production and composition and physiological state and where they reflect the underlying biology behind the incorporation of Se into milk. Selenium incorporation into milk of cows supplemented with Se yeast is largely the result of displacement of methionine with seleno-methionine derived from the Se yeast supplement during milk protein synthesis (Burk et al., 2001). This suggests that the total amount of Se secreted in milk of cows fed Se yeast will be influenced by the size of the pool of selenomethionine relative to methionine, the amount of milk protein synthesized, and the degree to which other tissues compete with the mammary gland for metabolites for protein synthesis. In the seasonal dairy production systems of northern Victoria, these components will be reasonably well described by the amount of Se fed to cows, protein yield, and stage of lactation (Walker et al., 2004). Using treatment averages from this study 

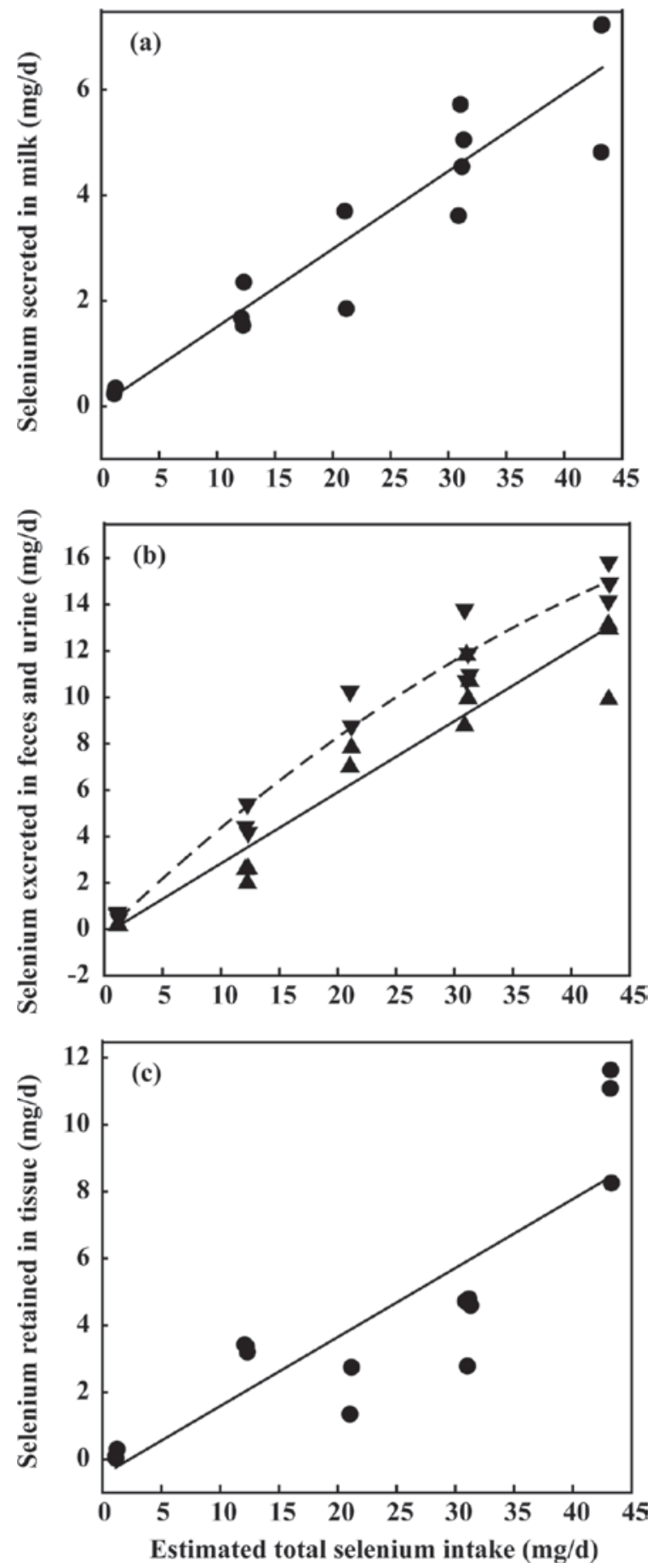

Figure 1. Relationships between the average total amount of Se (mg/cow per day) consumed by cows and the average amounts of $\mathrm{Se}(\mathrm{mg} / \mathrm{cow}$ per day) (a) secreted in milk, (b) excreted in feces $(\boldsymbol{\nabla}$; dashed line) and urine ( $\mathbf{\Delta}$; solid line), and (c) apparently retained in tissues. Milk $\mathrm{Se}=0.03( \pm 0.382)+0.15( \pm 0.014) \times$ total Se intake; $\mathrm{R}^{2}$ $=0.89(P<0.001)$; residual standard deviation $(\mathrm{RSD})=0.81 ; \mathrm{CV}=$ $24.4 \% ; \mathrm{n}=15$. Fecal $\mathrm{Se}=-0.16( \pm 0.607)+0.48( \pm 0.065) \times$ total Se intake $-0.003( \pm 0.0014) \times$ total Se intake ${ }^{2} ; \mathrm{R}^{2}=0.97(P<0.001)$; $\mathrm{RSD}=1.01 ; \mathrm{CV}=11.9 \% ; \mathrm{n}=15$. Urine $\mathrm{Se}=-0.23( \pm 0.660)+0.31$ $( \pm 0.025) \times$ total Se intake; $\mathrm{R}^{2}=0.92(P<0.001) ; \mathrm{RSD}=1.4 ; \mathrm{CV}$ $=21.1 \% ; \mathrm{n}=15$. Apparently retained $\mathrm{Se}=-0.48( \pm 0.873)+0.21$ $( \pm 0.033) \times$ total Se intake; $\mathrm{R}^{2}=0.76(P<0.001) ; \mathrm{RSD}=1.86 ; \mathrm{CV}$ $=44.8 \% ; \mathrm{n}=15$

Journal of Dairy Science Vol. 93 No. 10, 2010

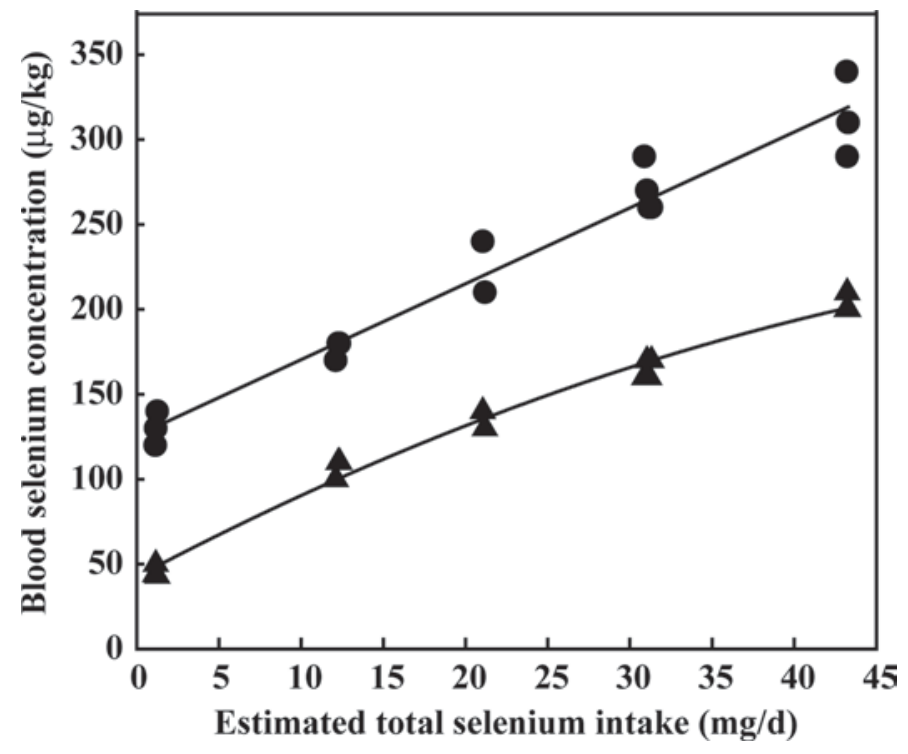

Figure 2. Relationships between the concentrations of Se $(\mu \mathrm{g} /$ $\mathrm{kg}$ ) in whole blood $(\bullet)$ and blood plasma $(\boldsymbol{\Delta})$ and total daily intake of Se by individual cows $(\mathrm{mg} / \mathrm{d})$. Whole blood $\mathrm{Se}=126( \pm 7.1)+4.5$ $( \pm 0.26) \times$ total Se intake; $\mathrm{R}^{2}=0.96(P<0.001)$; residual standard deviation $(\mathrm{RSD})=15.1 ; \mathrm{CV}=6.7 \% ; \mathrm{n}=15$. Blood plasma $\mathrm{Se}=43$ $( \pm 4.0)+5.1( \pm 0.43) \times$ total Se intake $-0.034( \pm 0.0094) \times$ total Se intake $^{2} ; \mathrm{R}^{2}=0.99(P<0.001) ; \mathrm{RSD}=6.7 ; \mathrm{CV}=5.0 \% ; \mathrm{n}=15$.

as well as those reported by Heard et al. (2007), more than $95 \%$ of the variation in the amount of Se secreted daily in milk ( $\mathrm{mg} / \mathrm{cow})$ could be predicted from total Se intake $(\mathrm{mg} / \mathrm{d})$, milk protein yield $(\mathrm{g} / \mathrm{d})$, and stage of lactation (as a pseudo-variable where early lactation $=$ -1 and late lactation $=+1)$ :

$$
\begin{gathered}
\text { Milk Se secretion }=-1.6( \pm 0.55)+0.15( \pm 0.007) \\
\times \text { total Se intake }+0.0026( \pm 0.0008) \times \text { protein } \\
\text { yield }-0.38( \pm 0.098) \times \text { stage of lactation; } \\
\mathrm{R}^{2}=0.98(P<0.001) ; \mathrm{RSD}=2.14 ; \\
\mathrm{CV}=8.8 \% ; \mathrm{n}=20
\end{gathered}
$$

Although this relationship explains most of the variation in the amount of Se secreted in milk in this case, no data exist for cows in mid lactation, cows that are significantly underfed, or cows with a requirement to use a proportion of ME intake for growth (e.g., heifers and cows in late pregnancy). Further research is needed to fill these gaps in information and to cover the range of situations that might occur in commercial dairy production systems.

Most of the Se (83\%) consumed by cows did not appear in milk but was either excreted or apparently retained in tissues. Both the retention of Se in tissues and 


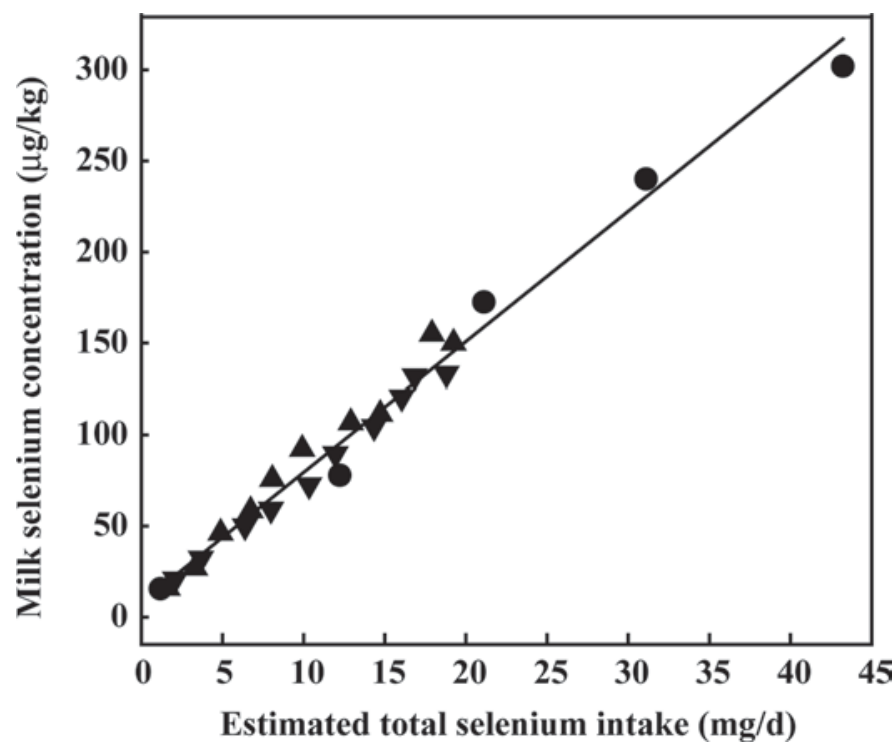

Figure 3. The relationship between the average concentration of Se in milk $(\mu \mathrm{g} / \mathrm{kg}$ of milk) and total Se intake $(\mathrm{mg} / \mathrm{cow}$ per day) in the current experiment $(\boldsymbol{\bullet})$ together with experiments $1(\mathbf{\Delta})$ and $2(\boldsymbol{\nabla})$ reported by Heard et al. (2007). Milk Se concentration $=8.0( \pm 3.02)+$ $7.1( \pm 0.19) \times$ total Se intake; $\mathrm{R}^{2}=0.98(P<0.001)$; residual standard deviation $=9.0 ; \mathrm{CV}=9.2 \% ; \mathrm{n}=25$.

excretion of Se by cows fed supplemental Se will result in a net gain of Se within a farm production system. Management strategies designed to produce Se-enriched milk on commercial dairy farms must, therefore, ensure that the other $83 \%$ of Se imported onto farms will not result in Se toxicosis in cows or farm ecosystems and that unacceptable concentrations of Se will not enter the food supply chain when cows are sold off the farm for meat or meat by-products.

The amount of Se apparently retained in tissues of cows was directly proportional to total Se intake. This is consistent with the findings of Heard et al. (2007) who reported that concentrations of Se in muscle tissue increased linearly as Se intake increased in dairy cows fed up to $16 \mathrm{mg}$ of Se/d from Se yeast over $6 \mathrm{wk}$. Extrapolating from the relationships reported by Heard et al. (2007), cows fed around $40 \mathrm{mg}$ of Se/d for $6 \mathrm{wk}$ would achieve a concentration of Se in muscle tissue of about $390 \mu \mathrm{g} / \mathrm{kg}$. This value comes within the upper ranges reported by McNaughton and Marks (2002) of Se concentrations found in fish, meat, and eggs offered for retail sale in Australia. Thus, cows consuming no more than $40 \mathrm{mg}$ of $\mathrm{Se} / \mathrm{d}$ for periods not exceeding 6 wk are unlikely to produce meat for consumption by humans or companion animals with unacceptably high concentrations of Se. It would be prudent, however, for quality assurance testing to be conducted on meat and offal from cows from commercial herds fed large amounts of Se before it enters the food chain.
A large proportion of the Se consumed by cows will eventually be distributed to the farm environment, with locations on farms where urine and feces tend to be concentrated such as yards and tracks around the dairy receiving a disproportionately high amount. Run-off and drainage from these areas are typically directed to effluent ponds so there is the potential for bioaccumulation of Se in farm effluent ponds, which increases the potential for toxicity to wildlife (Lemly, $1996,2002,2004)$. To make a crude assessment of the potential environmental effect that might result from feeding large amounts of Se to lactating cows, the likely addition of Se to farm areas through excretion products might be compared with the recommended rate of application of Se from fertilizers. Application of Se as sodium selenate of about 10,000 $\mathrm{mg} /$ ha every $12 \mathrm{mo}$ is reported to be adequate to maintain the Se concentration of fodder sufficient to prevent symptoms of Se deficiency in sheep and cattle (Watkinson, 1983; Stephen et al., 1989; Whelan and Barrow, 1994) and has a 20-fold safety margin for toxicity (Watkinson, 1983). Using the average total excretion of Se in urine plus feces derived in this study (66\%), feeding $40 \mathrm{mg}$ of $\mathrm{Se} /$ cow daily would result in the equivalent of $26.4 \mathrm{mg}$ of Se/cow per day being applied to the grazing area. Thus, it would take the daily feeding of $40 \mathrm{mg}$ of Se/ cow for $1 \mathrm{yr}$ at a stocking rate of about $1 \mathrm{cow} / \mathrm{ha}$ to apply 10,000 $\mathrm{mg}$ of Se/ha; therefore, it is unlikely that environmental issues would arise at this rate of feeding of Se. The main concerns with this conclusion are (1) that excreted Se will not be evenly distributed around a farm and (2) when tissue Se re-enters the bloodstream after supplementation with Se has ceased, some of it will continue to be partitioned to urine and will be excreted.

\section{CONCLUSIONS}

The total amount of Se secreted daily in milk from dairy cows fed up to about $40 \mathrm{mg} / \mathrm{d}$ of Se yeast can be accurately predicted from total Se intake, milk protein yield, and stage of lactation. Feeding Se yeast in quantities likely to be needed for the production of Se-enriched milk and dairy products for up to $6 \mathrm{wk}$ within a 12 -mo period is unlikely to lead to excessive concentrations of $\mathrm{Se}$ in muscle tissue of cows or to problems of bioaccumulation and toxicity in the environment on pasture-based dairy farms. Although the quantities of supplemental Se fed in this experiment are not universally permitted, if regulations were to change because of consumer demand for high-Se milk protein products for the enhancement of health, particularly in the elderly, the results presented here provide the basis for an on-farm strategy to significantly increase milk Se concentration. 


\section{ACKNOWLEDGMENTS}

Funding was provided by Tatura Milk Industries Pty. Ltd. (Tatura, VIC, Australia), Alltech Biotechnology P/L (Dandenong, VIC, Australia), the Geoffrey Gardiner Dairy Foundation (Melbourne, VIC, Australia), and the Victorian Department of Primary Industries (Melbourne, VIC, Australia). Valuable technical assistance was provided by Marg Jenkin, Stuart Austin, Daryl Wilson, Shelly Warde, and Allan Thorson and his farm staff, all of whom are located at the Victorian Department of Primary Industries' Kyabram Centre. Biometrics support was provided by Sorn Norng from the Knoxfield Centre of the Victorian Department of Primary Industries.

\section{REFERENCES}

Auldist, D. E., K. L. Atkinson, M. J. Silvapulle, D. W. Dellow, and G. H. McDowell. 1999. Utilisation of white clover silage fed alone or with maize silage by lactating dairy cows. Aust. J. Exp. Agric. 39:237-246.

Boldizarova, K., L. Gresakova, S. Faix, M. Mellen, and L. Leng. 2005. Antioxidant status of lambs fed on diets supplemented with selenite or Se-yeast. J. Anim. Feed Sci. 14:245-253.

Boldizarova, K., L. Gresakova, S. Faix, M. Levkut, and L. Leng. 2003. Urinary selenium excretion in selenite-loaded sheep and subsequent Se dynamics in blood constituents. Reprod. Nutr. Dev. 43:385-393.

Burk, R. F., K. E. Hill, and A. K. Motley. 2001. Plasma selenium in specific and non-specific forms. Biofactors 14:107-114.

Burk, R. F., R. J. Seely, and K. W. Kiker. 1973. Selenium: dietary threshold for urinary excretion in the rat. Proc. Soc. Exp. Biol. Med. 142:214-216.

Clarke, T., P. C. Flinn, and A. A. McGowan. 1982. Low-cost pepsincellulase assays for prediction of digestibility of herbage. Grass Forage Sci. 37:147-150.

CSIRO. 2007. Nutrient Requirements of Domesticated Ruminants. M Freer, H. Dove, and J. V. Nolan, ed. CSIRO Publ., Melbourne, Australia.

Earle, D. 1976. A guide to scoring dairy cow condition. J. Agric (Victoria) 74:228-231.

Foster, S. J., R. J. Kraus, and H. E. Ganther. 1986. The metabolism of selenomethionine, Se-methylselenocysteine, their selenonium derivatives, and trimethylselenonium in the rat. Arch. Biochem. Biophys. 251:77-86.

Heard, J. W., C. R. Stockdale, G. P. Walker, C. M. Leddin, F. R. Dunshea, G. H. McIntosh, P. M. Shields, A. McKenna, G. P. Young, and P. T. Doyle. 2007. Increasing selenium concentration in milk: Effects of amount of selenium from yeast and cereal grain supplements. J. Dairy Sci. 90:4117-4127.

Heard, J. W., G. P. Walker, P. Royle, G. McIntosh, and P. Doyle 2004. Effects of short-term supplementation with selenised yeast on milk production and composition of lactating cows. Aust. J. Dairy Technol. 59:199-203.

Hidiroglou, M., and I. Hoffman. 1975. Forms of selenium in urine of sheep. Ann. Biol. Anim. Biochim. Biophys. 15:583-588.
Hintze, K. J., G. P. Lardy, M. J. Marchello, and J. W. Finley. 2002 Selenium accumulation in beef: Effect of dietary selenium and geographical area of animal origin. J. Agric. Food Chem. 50:39383942.

Hu, Y., G. H. McIntosh, R. K. Le Leu, R. Woodman, and G. P. Young. 2008. Suppression of colon oncogenesis by selenium-enriched milk proteins: Apoptosis and K-ras mutations. Cancer Res. 68:49364944.

Hughes, J. W. 1963. Equipment for the separate and total collection of faeces and urine from dairy cattle. N. Z. J. Agric. Res. 6:127-139.

Khirwar, S. S., and S. P. Arora. 1975. Tissue distribution and excretion pattern of selenium-75 in animals. J. Nucl. Agric. Biol. 4:5-8.

Knowles, S. O., N. D. Grace, K. Wurms, and J. Lee. 1999. Significance of amount and form of dietary selenium on blood, milk, and casein selenium concentrations in grazing cows. J. Dairy Sci. 82:429-437.

Lemly, A. D. 1996. Assessing the toxic threat of selenium to fish and aquatic birds. Environ. Monit. Assess. 43:19-35.

Lemly, A. D. 2002. A procedure for setting environmentally safe total maximum daily loads (TMDLs) for selenium. Ecotoxicol. Environ. Saf. 52:123-127.

Lemly, A. D. 2004. Aquatic selenium pollution is a global environmental safety issue. Ecotoxicol. Environ. Saf. 59:44-56.

McIntosh, G., F. Dunshea, T. McKenna, G. Walker, Y. Hu, J. Heard, R. Stockdale, M. Shields, G. Young, and P. Doyle. 2008. A dairy source of organic selenium for health and wellbeing. Food Aust. 60:132-134.

McNaughton, S. A., and G. C. Marks. 2002. Selenium content of Australian foods: A review of literature values. J. Food Compost. Anal. 15:169-182.

Ortman, K., and B. Pehrson. 1997. Selenite and selenium yeast as feed supplements for dairy cows. Zentralbl. Veterinarmed. A 44:373380 .

Ortman, K., and B. Pehrson. 1999. Effect of selenate as a feed supplement to dairy cows in comparison to selenite and selenium yeast. J. Anim. Sci. 77:3365-3370.

Stephen, R. C., D. J. Saville, and J. H. Watkinson. 1989. The effects of sodium selenate applications on growth and selenium concentration in wheat. N. Z. J. Crop Hortic. Sci. 17:229-237.

Uglietta, R., P. T. Doyle, G. P. Walker, J. W. Heard, C. M. Leddin, C. R. Stockdale, G. H. McIntosh, G. P. Young, H. S. Gill, and F. R. Dunshea. 2008. Bioavailability of selenium from selenium-enriched milk assessed in the artificially-reared neonatal pig. Nutr. Dietetics 65(Suppl. 3):S37-S40.

Van Soest, P. J., J. B. Robertson, and B. A. Lewis. 1991. Methods for dietary fiber, neutral detergent fiber, and nonstarch polysaccharides in relation to animal nutrition. J. Dairy Sci. 74:3583-3597.

Walker, G. P., F. R. Dunshea, and P. T. Doyle. 2004. Effects of nutrition and management on the production and composition of milk fat and protein: A review. Aust. J. Agric. Res. 55:1009-1028.

Watkinson, J. H. 1983. Prevention of selenium deficiency of grazing animals by annual top-dressing of pasture with sodium selenate. N. Z. Vet. J. 31:78-85.

Whelan, B. R., and N. J. Barrow. 1994. Slow-release selenium fertilizers to correct selenium deficiency in grazing sheep in Western Australia. Fert. Res. Nutr. Cycl. Agroecosyst. 38:183-188.

Zayed, A., C. M. Lytle, and N. Terry. 1998. Accumulation and volatilization of different chemical species of selenium by plants. Planta 206:284-292. 